\title{
MODEL FOR FORMING AN INFORMATION SYSTEM OF PROJECT TEAMS IN A SECURITY-ORIENTED SYSTEM
}

The subject of the study is the personnel management information system. Infrastructure design processes of the framework model of complex socio-technical systems for project management and human resource management programs, formation of a database of members of project BOS teams and their evaluation using the index method to optimize the selection of project team members in a security-oriented system were studied. Purpose: to develop a model of an automated personnel management information system for implementation in the projects of security-oriented system using the index method of team members' evaluation. New models should be designed with the features of a complex socio-technical system and a sequence of implementation and adaptation stages in the project environment. This model should not be expensive to implement and take into account the life cycle processes of the organization from the selection of personnel to their management. Task: the information system of human resource management in projects of the security-oriented system is modeled. A set of software and hardware, telecommunications and organizational tools needed by a security-oriented organization for the functioning and interaction of communication and information flows has been worked out. Automation of selection and formation of project teams in complex socio-technical organizations is being developed due to the index assessment of candidates. The following methods are used: human resource management using automated HRM systems, expert information systems and index numerical indicators. The following results were obtained: a model of information expert system was developed and the process of knowledge accumulation due to software was described, an index method was proposed on the example of military formations in security-oriented systems. Conclusions: a generalized model-scheme of expert information system for personnel selection in security-oriented systems based on the index method has been developed.

Keywords: information system; security-oriented system; index method; human resource management; database; project teams.

\section{Introduction}

Human resource management is an important component for planning projects and programs, achieving the goals of the organization, its strategy, and mission. In the context of digitalization and turbulent changes, project and program management tools are very important. Modern methods of effective organization management are used to combine the main management objects, such as recruiting, team building, training, reporting and analysis, and other important processes in a single information environment. The development of management models in organizations requires new and individual approaches to the implementation and development of information systems in organizations. In a unified organization management system, it is the information system of human resources management that can provide high-quality and effective strategic planning and forecasting in the need to select and form competent teams, possible risks of internal and external project environment. These methods and models should be implemented in mega projects on civil protection of the population for automation and optimization of personnel processes.

In world practice, the most common information systems are: Oracle HCP cloud, SAP, ADP, Personality and others. However, the cost of implementing these systems is high, and the testing and optimization period can be years. In state-level projects, these systems are difficult to implement, they require an individual approach and taking into account the characteristics of all processes.

These methods and models should be implemented in mega projects for civil protection of the population where the number of employees is more than a thousand, in order to automate and optimize personnel processes. Socio-technical teams of complex security-oriented systems (SOS) provide services to support vital social functions that are important for industry, the economy, the functioning of society, public safety, the well-being of citizens and the environment. The information system includes the whole range of providing the necessary resources from the stakeholders of the state and private institutions and organizations for their preparation, development and support of the "product" of the life cycle, namely the formation of SOS teams and civil defense personnel.

\section{Analysis of research and publications}

The scientific works of the following domestic and foreign scientists are devoted to the study of methods and models of implementation of information systems in personnel management: Lysenko D.E. [9], Chumachenko I.V. [3], Bushuyev S.D. [1], Mikhnova A.V. [5], Mikhnov D.K. [5], Leli Yu. G. [6], Gogot M.M. [7], Chuprina M.O. [7], Golovan D.V. [8], Zachko O.B. [12], Makarova M.V. [13], Ruchka T.I. [13], Tesla Yu. M. [4], Biloshitsky A.O. [4], Tesla N. Yu. [4], Okhrimenko V.M. [10], Voronkova T.B. [10] and others.

Lysenko D.E. in his works [9] developed methods and models for selection into project team members, using the theory of precedents as a basis for experience to implement new tasks. The developed structure of the qualimetric model allows to mathematically calculate and display the relationships between the input tasks, the base of precedents and their evaluation, candidates for the role in the project and other actors for the formation of the project team. This model should be considered for recruitment and integration of decision support system (DSS) with the information system of human resources management.

Bushuyev S.D. in his works [1] studied the processes of project knowledge management and developed a conceptual model that allows you to structure data, information and turn them into knowledge. These 
developments should be taken into account when developing new models of human resource management information systems in the field of security - oriented system for data presentation in the information environment.

In the monograph of Chumachenko I.V. [3] special attention is paid to multi-projects, which are relevant in a complex socio-technical system where projects are constantly growing and require effective tools for selecting and forming teams in a dynamic environment, as well as interaction between stakeholders, distribution of tasks and project resource management.

The scientific works of Tesla A.V. [4] reflect the formalization of project management tools using an information system based on the goals and strategies of the organization, as well as on the means of project administration. When analyzing software tools for automation of project resource planning, the company operates more efficiently and for implementation in a particular area should analyze the features of the system, which will be improved by the information system.

In his work Gogot M.M. [7] explored the use of modern information technology in the context of human resource management. To achieve success in the organization, HR management must provide real-time management of the ranks of strategy, tactics and operational activities, which requires the development of new information system models for megaprojects.
The article by Golovan D.V. [8] considerable attention focuses on the improvement of automated personnel management systems through the methodical implementation of multifunctional expert systems for career guidance, selection and certification of employees.

In his work Zachko O.B. [12] paid considerable attention to the study of safety principles, security management, as well as the management of information systems in civil defense. A model of the information system should be developed using the data of experience and research.

\section{Presentation of the main material}

The choice of a human resources management information system depends on a number of criteria, such as the cost of implementing the system, the strategy and specifics of the organizations, the implementation period, the number of employees, operational features and the need for additional modules, such as recruitment.

Outdated human resource management methods lead to deteriorating performance and efficiency in general, due to the difficulty of coordination, monitoring and control of the accumulated organizational structure, as a result: low feedback speed, inefficient performance of tasks and lack of data analysis to manage and pursue the chosen mission, strategy, achieving goals. Below is a comparative table 1 of human resource management by new and standard methods.

Table 1. Comparative analysis of human resource management between standard and new methods

\begin{tabular}{|c|l|l|}
\hline 1 & $\begin{array}{l}\text { (HR standards): standard methods of human resource } \\
\text { management }\end{array}$ & $\begin{array}{l}\text { (HRIS): implementation of a human resources management } \\
\text { information system }\end{array}$ \\
\hline 2 & $\begin{array}{l}\text { Definition of system and document management } \\
\text { requirements }\end{array}$ & $\begin{array}{l}\text { Project management tools are adapted to the goals, mission and } \\
\text { strategy of the system in the conceptual core }\end{array}$ \\
\hline 3 & $\begin{array}{l}\text { Human resources for the management of the stages of } \\
\text { selection, adaptation, training are allocated to } \\
\text { individual projects }\end{array}$ & $\begin{array}{l}\text { Management of human resources, recruitment and the main stages of } \\
\text { the life cycle of project team members is carried out in a single } \\
\text { information environment, which allows you to free up resources, } \\
\text { direct them to other tasks, quick feedback and more efficient } \\
\text { organization of work compared to manual administrative } \\
\text { management HR standards }\end{array}$ \\
\hline 4 & $\begin{array}{l}\text { Salary, staff turnover, control and monitoring } \\
\text { management is entrusted to individual managers, } \\
\text { whose interaction slows down the speed of information } \\
\text { transfer }\end{array}$ & $\begin{array}{l}\text { Remuneration management, staff turnover, monitoring and control } \\
\text { are interrelated in the information system, which allows you to } \\
\text { comprehensively evaluate and analyze the results and effectiveness } \\
\text { of management. }\end{array}$ \\
\hline 5 & $\begin{array}{l}\text { Risk management is difficult to operate and analyze } \\
\text { the potential consequences on the basis of data that do } \\
\text { not reflect reality }\end{array}$ & $\begin{array}{l}\text { Thanks to a single module of reporting and analysis of the } \\
\text { information space, it is possible to compare the planned indicators } \\
\text { with the planned ones, which allows to achieve the goals of projects } \\
\text { in complex socio-technical systems. }\end{array}$ \\
\hline
\end{tabular}

In complex socio-technical systems, such as civil protection against emergencies, the management of available resources is an important component that influences the success of projects. Inefficient management leads to disastrous consequences, for this purpose it is necessary to analyze the current situation in order to be able to automate and optimize personnel processes through the introduction of an information system. Rational redirection of human resources will allow for more effective coordination with a security- oriented system. Below here is fig. 1, which analyzes the priority tasks for project implementation and monitoring of the main tasks carried out through standard management methods and HRIS information systems.

The implementation of the information system is possible through five phases:

1. Planning (transition from the usual management methods to the need for an information system);

2. Analysis (current situation - "bottlenecks" for process optimization; 
3. Development of an information system based on the selected model;

4. Implementation of HRIS with databases, selection module based on the index method;

\section{System maintenance and testing.}

HRIS actors need to be identified to develop an information system. The prototype is shown in fig. 2 .

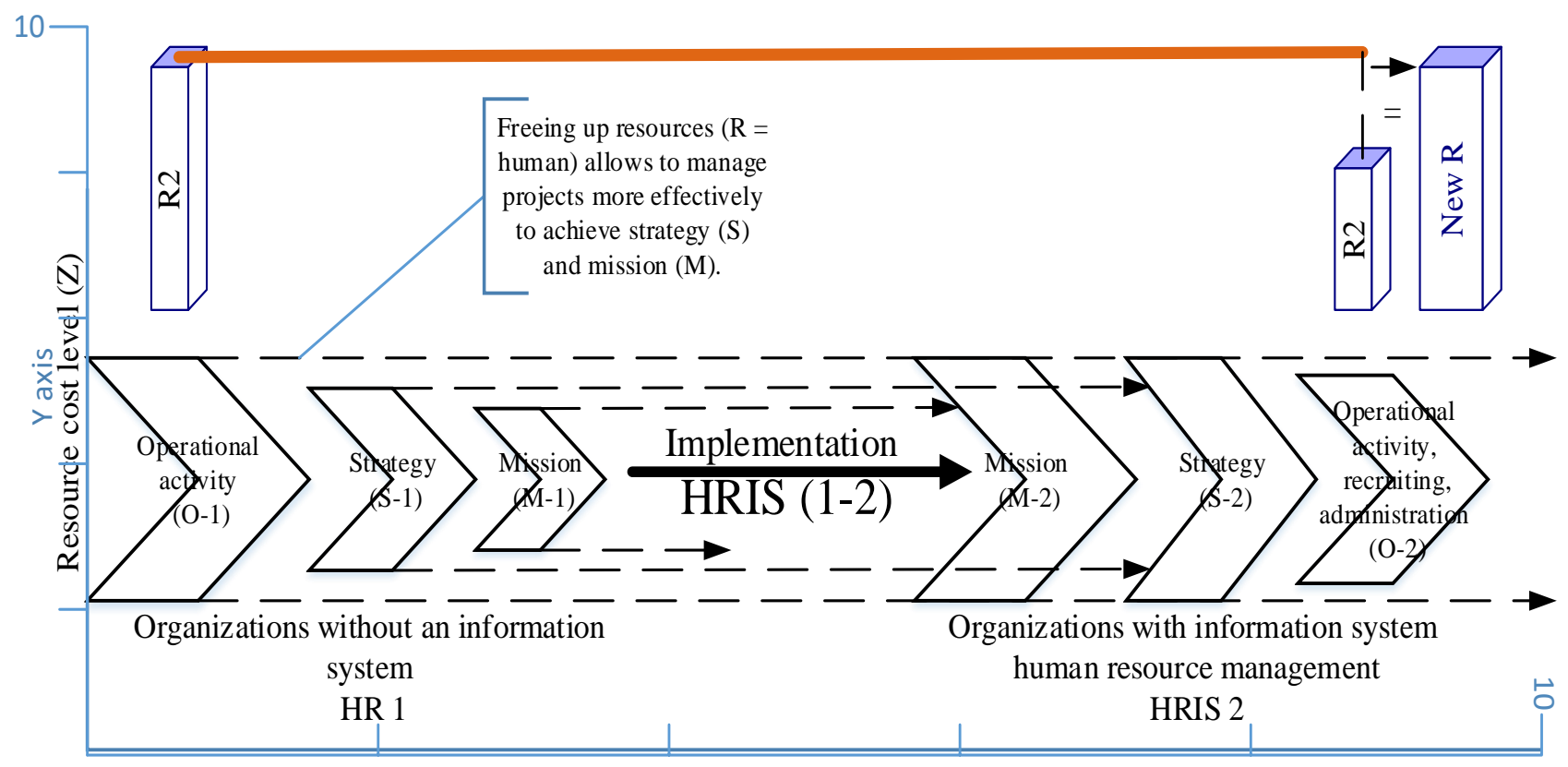

O $\quad \mathrm{X}$ axis $\quad$ Resource management $(\mathrm{R})$

Fig. 1. Model of optimization of human resources management in SOS

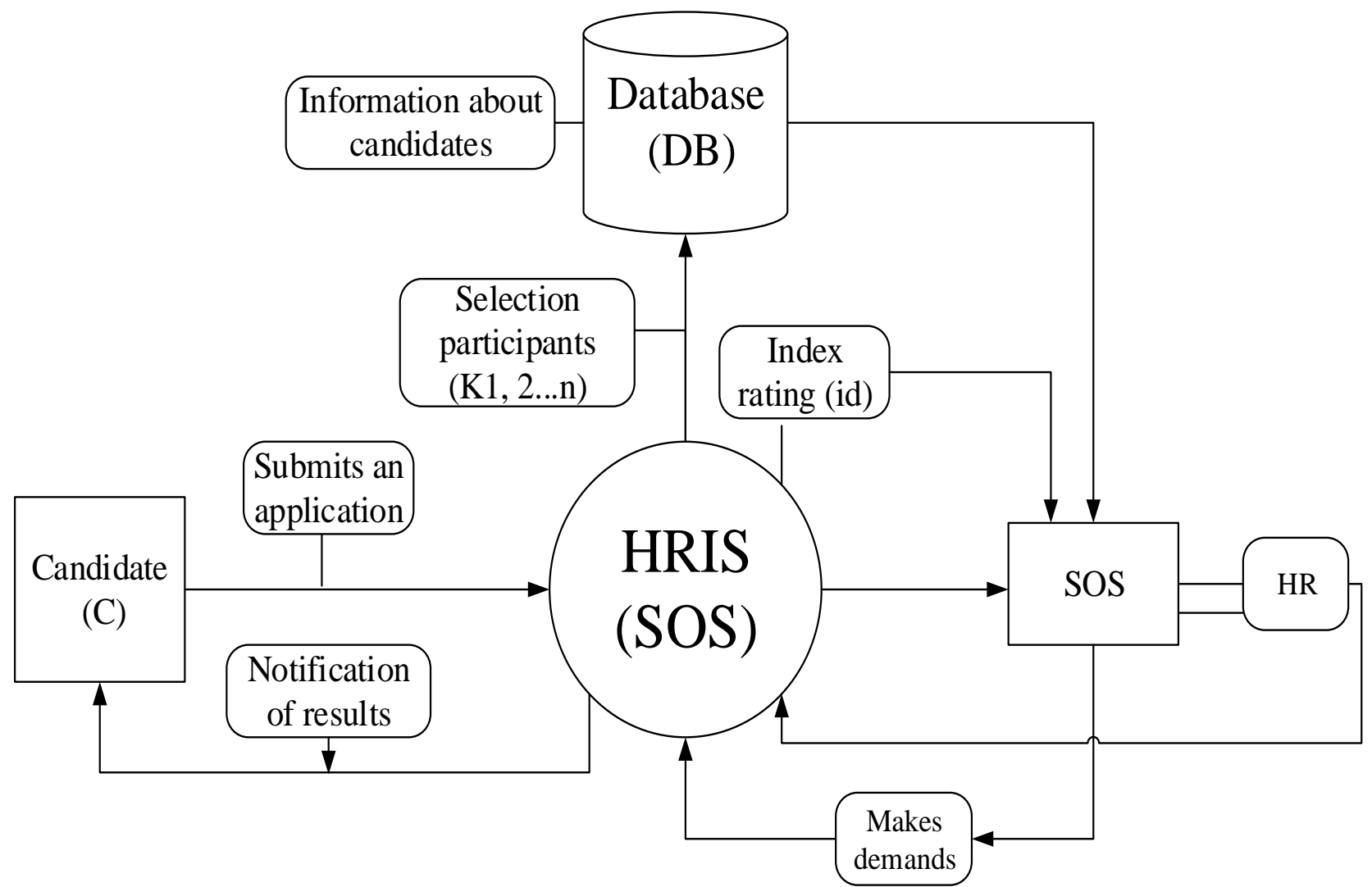

Fig. 2. Model-scheme of interaction of information system users in SOS

The input data should be information about the candidates: name, surname, date of birth and other items that with the flow of data will form the relationship of databases (fig. 3) for the information system. 


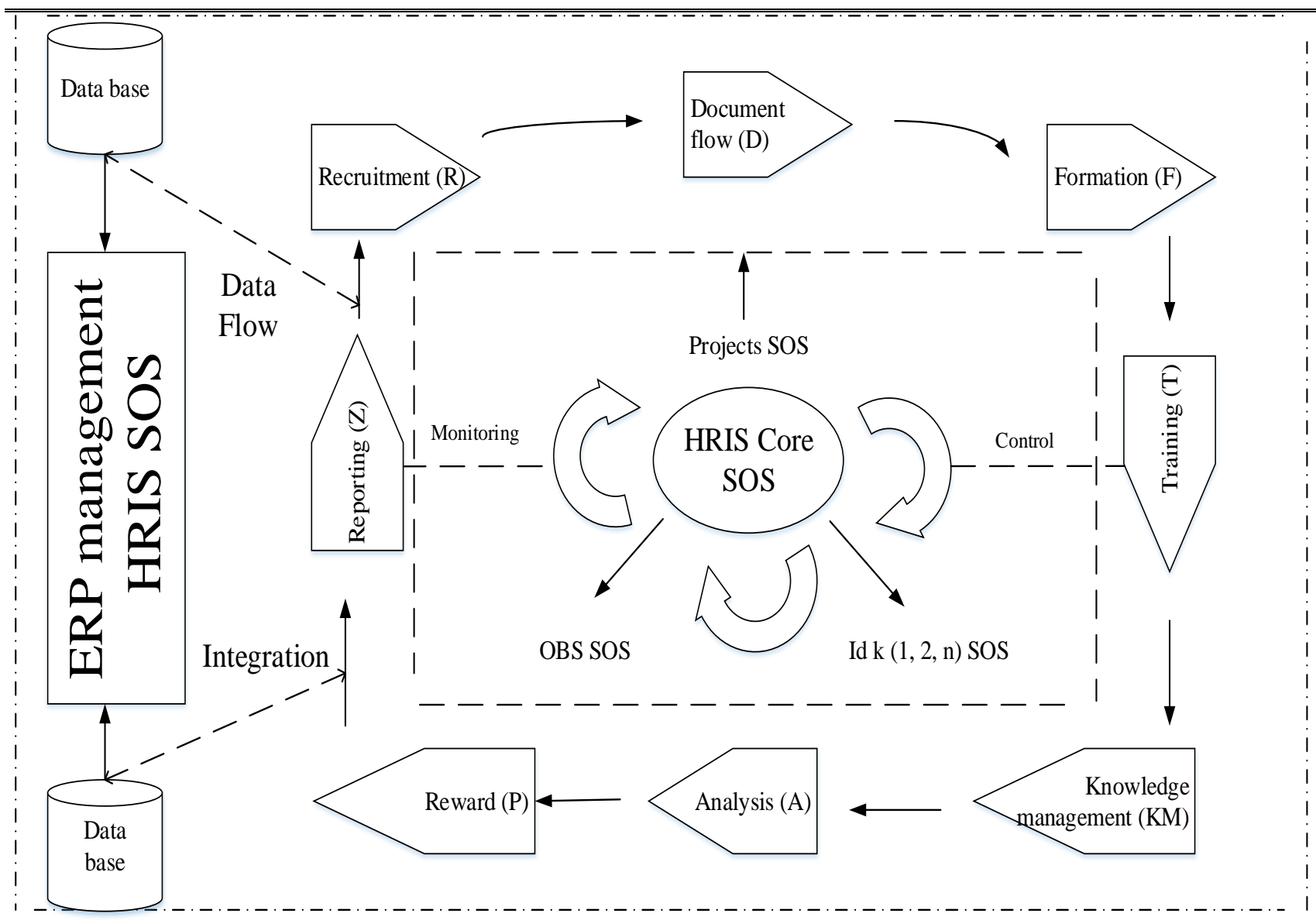

Fig. 3. Model of database integration with information system processes

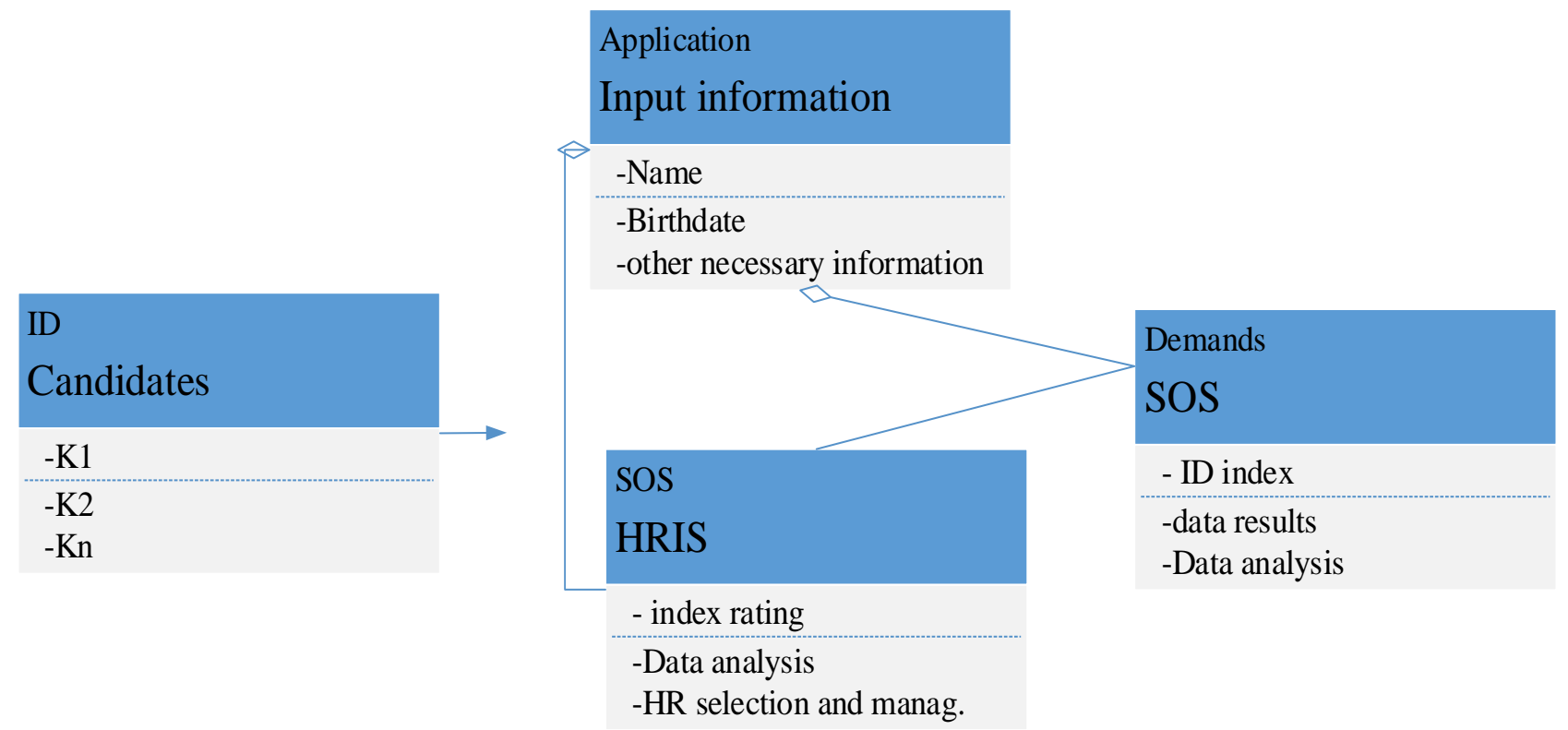

Fig. 4. Database model for integration

The effectiveness of human resource management is represented by formula 1

$(E)=$ recruiting $(R)+$ formation $(F)+$ training $(D)+$ management $(\mathrm{M})+$ control $(\mathrm{C})$;

$$
\mathrm{HR}=\mathrm{R}+\mathrm{F}+\mathrm{D}+\mathrm{M}+\mathrm{C}=5 \text {; }
$$

HRIS $=\mathrm{MC}=2.5$ (process optimization by $50 \%)$.
The integration of the information system should take into account the external and internal design environment of the security-oriented system (fig. 5).

An important factor in the functioning of the information system is its constant adaptation to change through cyclic testing (fig. 6). 


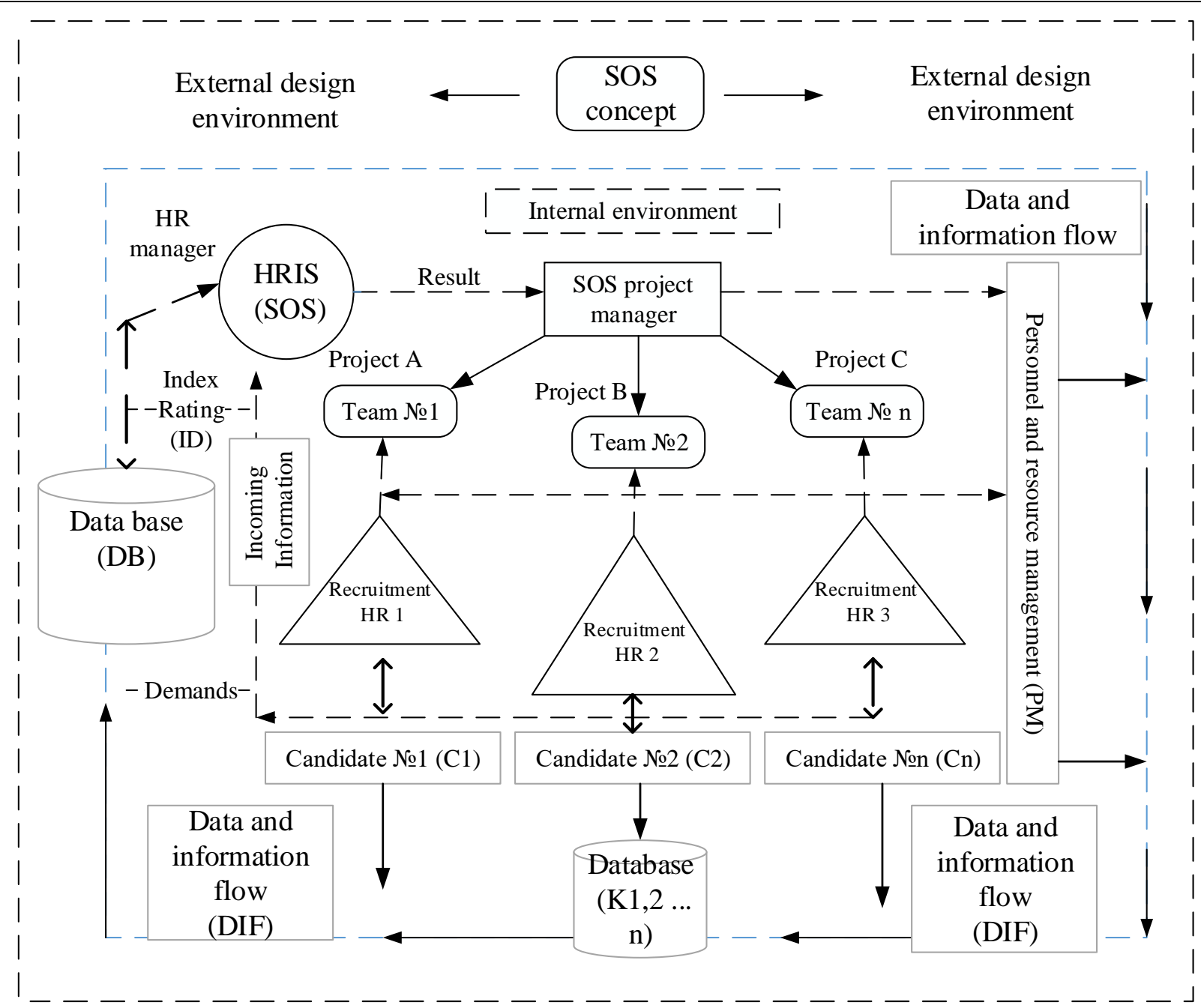

Fig. 5. Model of information system implementation in SOS environment

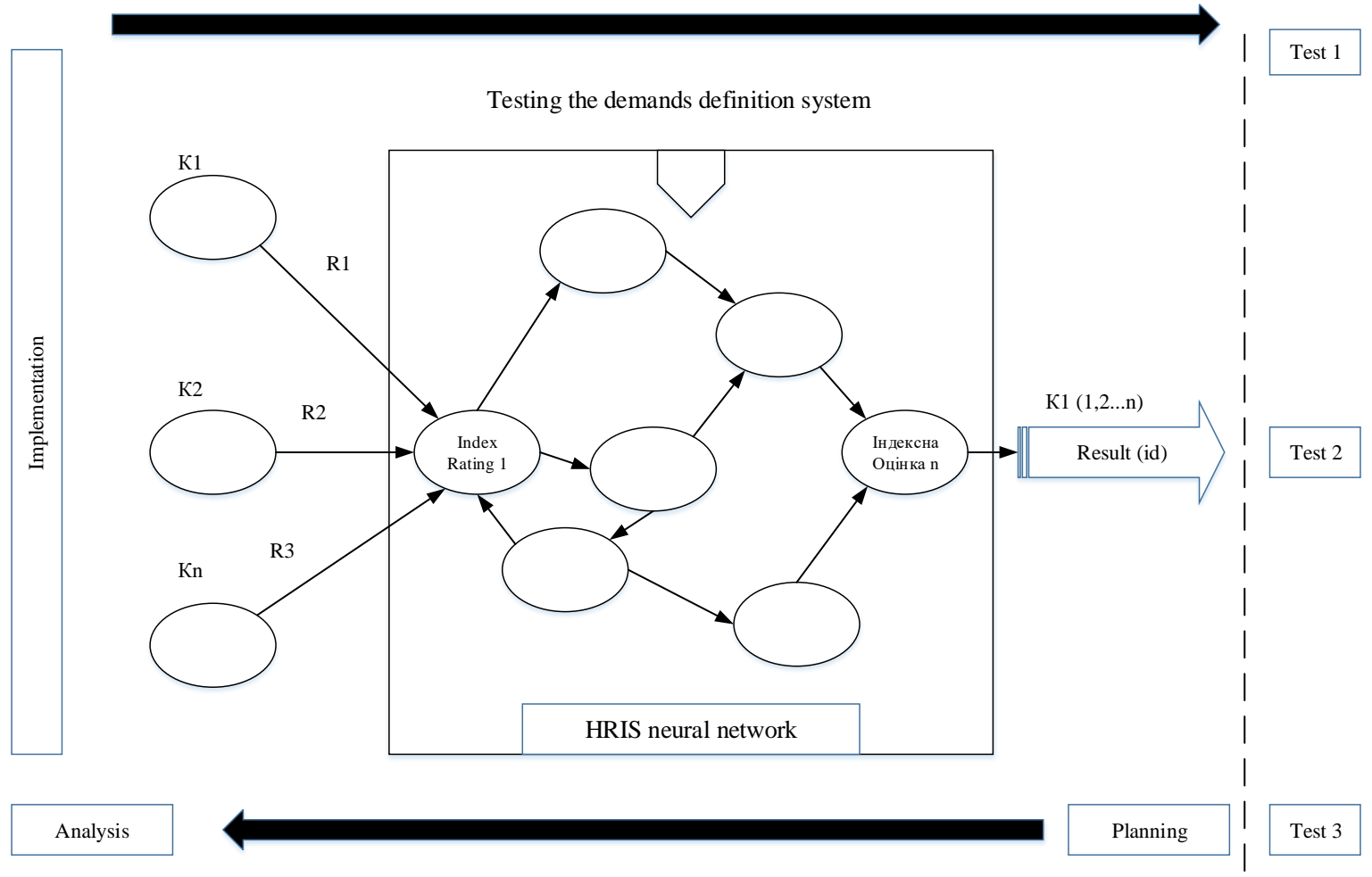

Fig. 6. Information system testing model 


\section{Index method}

Thanks to index methods, it is possible to measure the observed indicators and factors for further expert evaluation. Index method (popular and powerful informative toolkit), which is aimed at a general quantitative study of the degree of influence of individual factors on the overall result using relative values. This method should be used for systematic analysis of the performance of individual team members, which is the amount of work performed per unit time (in our case - the results of the competition, which will be taken into account in evaluating participants) with a relative comparison of the portrait of the "ideal candidate", that is:
$W n=Q n / Q o$,

where $W n$ is a relative indicator of the rating of the candidate of the competition-selection to the project team of the security-oriented system. The value of performance $W n$ allows to expertly analyze and compare the evaluation results with the selection criteria, which will be used in the automated program of the optimized selection process and the formation of a project team in a security-oriented system; $Q n$ is the result of the points scored at the stages of the competition-selection by the $n$-th participant; $Q o$ is the relative quantitative value of the "ideal portrait of the candidate" for the successful outcome of the project of selection in the security-oriented system of the serviceman.

Table 2. Index evaluation of candidates for SOS projects

\begin{tabular}{|c|c|c|c|c|}
\hline $\begin{array}{l}\text { Rating-selection } \\
\text { No. }\end{array}$ & $\begin{array}{l}\text { Number (ID) of the candidate for participation in the project } \\
\text { "security-oriented system" }\end{array}$ & $Q n$ & Qo & $W n$ \\
\hline 1 & 1 & $<0,9$ & 1 & $0,1-0,9$ \\
\hline 2 & 2 & $<0,9$ & 1 & $0,1-0,9$ \\
\hline 3 & 3 & $<0,9$ & 1 & $0,1-0,9$ \\
\hline 4 & 4 & $<0,9$ & 1 & $0,1-0,9$ \\
\hline$\ldots$ & $\ldots$ & 0,6 & 1 & $0,1-0,9$ \\
\hline $\mathrm{n}$ & $\mathrm{n}$ & 0,4 & 1 & $0,1-0,9$ \\
\hline
\end{tabular}

Table of initial and calculated data for expert assessment of the rating of candidates in the information system for decision support of DSS.

\section{Conclusions}

In this paper, we have analyzed information systems for human resource management and selection criteria for complex socio-technical systems. A model of information system formation for its implementation in security - oriented systems for automation and optimization of personnel processes for human resources management has been developed. A module for selection of candidates for project teams of security-oriented systems based on the index method for further formation of the project team has been introduced into the information system. A model for testing new information systems, as well as system integration with databases that improve the efficiency of process management at all levels of the life cycle of employees and the organization.

\section{References}

1. Bushuyev, S. D. (2012), "Conceptual model of project knowledge management".

2. Bushuyev, S. D. (2010), "Project management: basics of professional knowledge and system of assessment of competence of project managers", Kyiv, IRIDUM, 208 p.

3. Chumachenko, I. V., Dotsenko, N. V., Sabadosh, L. Yu. (2015), "Methods of forming human resources of multiproject teams and programs" ["Metody formuvannia liudskymy resursamy multyproektnykh komand ta prohram"], Monograph, $202 \mathrm{p}$.

4. Tesla, Yu. M., Biloshitsky, A. A., Tesla, N. Yu. (2010), Information technology of project management on the basis of ERPP (Enterprise resources planning in project) and APE (Administrated projects of the enterprise) systems, Kyiv National University of Construction and Architecture, Kyiv, P. 1-20.

5. Mikhnova, A., Mikhnov, D., Chyrkova, K. (2019), "Method for evaluating the efficiency of upgrading specialized information systems", Innovative Technologies and Scientific Solutions for Industries, No. 4 (10), P. 69-76. DOI: https://doi.org/10.30837/25229818.2019.10.069

6. Leli, Yu. G. (2015), "Analysis of existing automated personnel management systems at domestic enterprises", State and regions. Series, Economics and Entrepreneurship, No. 2, P. 49-52.

7. Gogot, M. M., Chuprina, M. O. (2017), "The use of information systems in personnel management" ["Vykorystannya informatsiynykh system v upravlinni personalom"], Current issues of economics and science: Collection of scientific works of the Faculty of Management KPI. I. Sikorsky, No. 11, P. 3-7.

8. Golovan, D. V. (2013), "Application of modern automated personnel management systems at the enterprise" ["Zastosuvannya suchasnykh avtomatyzovanykh system upravlinnya personalom na pidpryyemstvi"], Economics and management of machine-building enterprises: problems of theory and practice, No. 1 (21), P. 2-7.

9. Lysenko, D. E. (2009), "Models and methods of forming a project team using precedent theory" ["Modeli ta metody formuvannia komandy proektu z vykorystanniam teorii pretsedentiv"], abstract, Kharkiv, P. 6-15.

10. Okhrimenko, V. M., Voronkova, T. B. (2006), "Information systems and technologies at enterprises" ["Informatsiini systemy i tekhnolohii na pidpryiemstvakh "], Lecture notes (for students and students of FEF and FE specialty "Economics of Enterprise", Kharkiv, KNAMG, 185 p.

11. Zachko, O., Kobylkin, D., Kovalchuk, O. (2019), "Models of project teams' formation in a safety-oriented system", Innovative Technologies and Scientific Solutions for Industries, No. 4 (10), P. 85-91. DOI: https://doi.org/10.30837/2522-9818.2019.10.085 
12. Zachko, O. B. (2019), Safety logical bases of management of information systems and projects in civil protection, Monograph, Lviv, Publisher LSULS, 325 p.

13. Makarova, M. V., Ruchka, T. I. (2014), "Introduction of personnel management information systems in the activity of an insurance company" ["Zaprovadzhennya informatsiynykh system upravlinnya personalom v diyal'nosti strakhovoyi kompaniyi"], Scientific works of DonNTU. Series: Economic, No. 4, P. 2-8.

14. Johnson, R. D., Gueutal, H. G. (2011), "Transforming HR Through Technology. The Use of E-HR and HRIS in Organizations", Research report nonprofit affiliate of the Society for Human Resource Management (SHRM practice guidelines series), P. 11-36, available at: www.shrm.org/foundation

15. Dorel Dusmanescu, Aleksandra Bradic-Martinovic (2011), "The Role of Labour Markets and Human Capital in the Unstable Environment. The role of information systems in human resource management", Research monograph, Chapter 2, P. $25-45$.

16. Daniel Mueller, Stefan Strohmeier, Christian Gasper (2010), "HRIS Design Characteristics: Towards a General Research Framework", Proceedings of the Third European Academic Workshop on electronic Human Resource Management, Bamberg, Germany, May 20-21, 2010, Vol. 570, P. 250-267.

17. Marie Christine M. Banaria, Erica Joi W. Ang, Wardylene P. Majan, Giuseppe Ng. (2018), "Developing a Human Resource Information System through Hybrid Software Engineering Model", University of Asia and the Pacific, Conference: Make SEnS Research Colloquium, April 2018, P. 2-7, available at : https://www.researchgate.net/publication/327061977

18. Barkha Gupta (2013), Journal of Business and Management (IOSR-JBM), Vol. 13, Issue 6, P. 41-46

19. Md Golam Rabiul Alam, Abdul Kadar Muhammad Masum, Loo-See Beh, Choong Seon Hong (2016), "Critical Factors Influencing Decision to Adopt Human Resource Information System (HRIS) in Hospitals", PLoS ONE, No. 11 (8) DOI: https://doi.org/10.1371/journal.pone.0160366

20. Hilkka Poutanen, Vesa Puhakka (2007), Developing the Initial Framework of HRIS", Proceedings of the 1st International Workshop on Human Resource Information Systems, P. 45-54. DOI: 10.5220/0002415200450054

21. Sanjay Mohapatra (2009), "Framework for HRIS Implementation in Non-IT Sector", Journal of Convergence Information Technology, Vol. 4, No. 4.

22. Guide to the Project Management Body of Knowledge (PMBOK® Guide) (2017), Sixth Edition. Project Management Institute. Publications.

23. P2M A Guidebook of Project \& Program Management for Enterprise Innovation (2015), available at http://www.pmaj.or.jp/ENG/.

Received 28.05.2020

Відомості про авторів / Сведения об авторах / About the Authors

Зачко Олег Богданович - доктор технічних наук, професор, Львівський державний університет безпеки життєдіяльності, професор кафедри права та менеджменту у сфері цивільного захисту, Львів, Україна; email: zachko@ukr.net; ORCID: https://orcid.org/0000-0002-3208-9826.

Зачко Олег Богданович - доктор технических наук, профессор, Львовский государственный университет безопасности жизнедеятельности, профессор кафедры права и менеджмента в сфере гражданской защиты, Львов, Украина.

Zachko Oleh - Doctor of Sciences (Engineering), Professor, Lviv State University of Life Safety, Professor of the Department of Law and Management in the Field of Civil Protection, Lviv, Ukraine.

Кобилкін Дмитро Сергійович - кандидат технічних наук, доцент, Львівський державний університет безпеки життєдіяльності, доцент кафедри пожежної тактики та аварійно-рятувальних робіт, Львів, Україна; email: dmytrokobylkin@gmail.com; ORCID: https://orcid.org/0000-0002-2848-3572.

Кобылкин Дмитрий Сергеевич - кандидат технических наук, доцент, Львовский государственный университет безопасности жизнедеятельности, доцент кафедры пожарной тактики и аварийно-спасательных работ, Львов, Украина

Kobylkin Dmytro - PhD (Engineering Sciences), Associate Professor, Lviv State University of Life Safety, Associate Professor of the Department of Fire Tactics and Rescue Operations, Lviv, Ukraine.

Ковальчук Олег Ігорович - Львівський державний університет безпеки життєдіяльності, ад'юнкт кафедри права та менеджменту у сфері цивільного захисту, Львів, Україна; email: Justdoitolejka@gmail.com; ORCID: https://orcid.org/00000001-6584-0746.

Ковальчук Олег Игоревич - Львовский государственный университет безопасности жизнедеятельности, адъюнкт кафедры права и менеджмента в сфере гражданской защиты, Львов, Украина.

Kovalchuk Oleh - Lviv State University of Life Safety, Adjunct of the Department of Law and Management in the field of civil protection, Lviv, Ukraine.

Марков В'ячеслав Валерійович - кандидат юридичних наук, старший науковий співробітник, Харківський національний університет внутрішніх справ, декан, Харків, Україна; email: cyber_hnuvs@i.ua; ORCID: http://orcid.org/00000003-2024-657X.

Марков Вячеслав Валерьевич - кандидат юридических наук, старший научный сотрудник, Харьковский национальный университет внутренних дел, декан, Харьков, Украина.

Markov Viacheslav - PhD (Juridical Sciences), Senior Researcher, National University of Internal Affairs, Dean, Kharkiv, Ukraine. 


\title{
МОДЕЛЬ ФОРМУВАННЯ ІНФОРМАЦЙНОЇ СИСТЕМИ ПРОСКТНИХ КОМАНД В БЕЗПЕКО-ОРІЄНТОВАНІЙ СИСТЕМІ
}

\begin{abstract}
Предметом дослідження є інформаційна система управління персоналом. Процеси проєктування інфраструктури моделі фреймворку складних соціотехнічних систем з управління проєктами та програмами менеджменту людських ресурсів, формування бази даних членів проєктних БОС команд та їх оцінки використовуючи індексний метод для оптимізації процесів відбору членів проєктних команд в безпеко-орієнтованій системі. Мета роботи: розроблення моделі автоматизованої інформаційної системи управління персоналом для впровадження в проєктах безпеко-орієнтованої системи 3 використанням індексного методу оцінки членів команд. Нові моделі слід проєктувати з особливостями складної соціотехнічної системи та послідовністю етапів впровадження і адаптації в проєктному середовищі. Дана модель повинна бути не дорогою для впровадження і враховувати процеси життєвого циклу організації починаючи 3 відбору персоналу до їх управління. Завдання: моделюється інформаційна система управління людським ресурсом в проєктах безпеко-орієнтованої системи. Комплекс програмно-технічних, телекомунікативних та організаційних засобів, необхідних безпеко-орієнтованій організації для функціонування й взаємодії комунікативно-інформаційних потоків. Розробляється автоматизація процесів відбору та формування проєктних команд в складних соціотехнічних організаціях завдяки індексній оцінці кандидатів. Використовуються такі методи: управління людськими ресурсами з використанням автоматизованих НRM систем, експертні інформаційні системи та індексні числові показники. Отримано наступні результати: розроблено модель інформаційної експертної системи та описано процес накопичення знань завдяки програмному забезпеченню, запропоновано індексний метод на прикладі військових формувань у безпеко-орієнтованих системах. Висновки: розроблено узагальнену модельсхему експертної інформаційної системи для відбору кадрів у безпеко-орієнтовані системи на основі індексного методу.

Ключові слова: інформаційна система; безпеко-орієнтована система; індексний метод; управління людськими ресурсами; база даних; проєктні команди.

\section{МОДЕЛЬ ФОРМИРОВАНИЯ ИНФОРМАЦИОННОЙ СИСТЕМЫ ПРОЕКТНЫХ КОМАНД В БЕЗОПАСНОСТИ-ОРИЕНТИРОВАННОЙ СИСТЕМЕ}

Предметом исследования является информационная система управления персоналом. Процессы проектирования инфраструктуры модели фреймворка сложных социотехнических систем по управлению проектами и программами менеджмента человеческих ресурсов, формирование базы данных членов проектных БОС команд и их оценки используя индексный метод для оптимизации процессов отбора членов проектных команд в безопасности-ориентированной системе. Цель работы: разработка модели автоматизированной информационной системы управления персоналом для внедрения в проектах безопасность-ориентированной системы с использованием индексного метода оценки членов команд. Новые модели следует проектировать с особенностями сложной социотехнической системы и последовательностью этапов внедрения и адаптации в проектном среде. Данная модель должна быть не дорогой для внедрения и учитывать процессы жизненного цикла организации начиная с отбора персонала к их управлению. Задачи: моделируется информационная система управления человеческим ресурсом в проектах безопасность-ориентированной системы. Комплекс программнотехнических, телекоммуникативной и организационных средств, необходимых безопасность-ориентированной организации для функционирования и взаимодействия коммуникативно-информационных потоков. Используются такие методы: управление человеческими ресурсами с использованием автоматизированных HRM систем, экспертные информационные системы и индексные числовые показатели. Получены следующие результаты: разработана модель информационной экспертной системы и описан процесс накопления знаний благодаря программному обеспечению, предложено индексный метод на примере военных формирований в безопасности-ориентированных системах. Выводы: разработана обобщенная модель-схему экспертной информационной системы для отбора кадров в безопасности ориентированные системы на основе индексного метода.

Ключевые слова: информационная система; безопасность-ориентированная система; индексный метод; управления человеческими ресурсами; база данных; проектные команды.

\section{Бібліографічні описи / Bibliographic descriptions}

Зачко О. Б., Кобилкін Д. С., Ковальчук О. І., Марков В. В. Модель формування інформаційної системи проєктних команд в безпеко-орієнтованій системі. Сучасний стан наукових досліджень та технологій в промисловості. 2020. № 2 (12). C. 49-56. DOI: https://doi.org/10.30837/2522-9818.2020.12.049.

Zachko, O., Kobylkin, D., Kovalchuk, O., Markov, V. (2020), "Model for forming an information system of project teams in a security-oriented system", Innovative Technologies and Scientific Solutions for Industries, No. 2 (12), P.49-56. DOI: https://doi.org/10.30837/2522-9818.2020.12.049. 